\title{
Cardosins in postembryonic development of cardoon: towards an elucidation of the biological function of plant aspartic proteinases
}

\author{
Cláudia Sofia Pereira ${ }^{1}$, Diana Soares da Costa ${ }^{1,2}$, Susana Pereira ${ }^{2}$, F. de Moura Nogueira ${ }^{2}$, \\ P. M. Albuquerque ${ }^{1}$, J. Teixeira ${ }^{2}$, C. Faro $^{3}$, J. Pissarra ${ }^{1,2}$ \\ ${ }^{1}$ Institute for Molecular and Cell Biology, University of Porto, Porto \\ ${ }^{2}$ Faculty of Sciences, University of Porto, Porto \\ ${ }^{3}$ Center for Neuroscience, Instituto Biomedico de Investigação da Luz e da Imagem, University of Coimbra, Coimbra
}

Received 10 May 2007; Accepted 30 August 2007; Published online 30 April 2008

(c) Springer-Verlag 2008

\begin{abstract}
Summary. Following on from previous work, the temporal and spatial accumulation of the aspartic proteinases (EC 3.4.23) cardosin A and cardosin B during postembryonic seed development of cardoon (Cynara cardunculus) was studied. mRNA and protein analyses of both cardosins suggested that the proteins accumulate during seed maturation, and that cardosin A is later synthesised de novo at the time of radicle emergence. Immunocytochemistry revealed that the precursor form of cardosin A accumulates in protein bodies and cell walls. This localisation in seeds is different from that previously described for cardoon flowers, suggesting a tissue-dependent targeting of the protein. It is known that procardosins are active and may have a role in proteolysis and processing of storage proteins. However, the presence of procardosin A in seeds could be related to the proposed role of the plant-specific insert in membrane lipid conversion during water uptake and solute leakage in actively growing tissues. This is in accordance with the recently proposed bifunctional role of aspartic proteinase precursor molecules that possess a membranedestabilising domain in addition to a protease domain. Mature cardosin $\mathrm{B}$, but not its mRNA, was detected in the first hours after seed imbibition and disappeared at the time of radicle emergence. This extracellular aspartic protease has already been implicated in cell wall loosening and remodelling, and its role in seed germination could be related to loosening tissue constraints for radicle protusion. The described pattern of cardosin $\mathrm{A}$ and $\mathrm{B}$ expression suggests a finely tuned developmental regulation and prompts an analysis of their possible roles in the physiology of postembryonic development.
\end{abstract}

Keywords: Aspartic proteinase; Seed; Cardosin; Protein body; Plantspecific insert of aspartic proteinase; Cynara cardunculus.

\section{Introduction}

Aspartic proteinases (APs) make up a class of endopeptidases (EC 3.4.23) that is widely distributed in vertebrates,

Correspondence: C. S. Pereira, Institute for Molecular and Cell Biology, Rua do Campo Alegre 823, 4150-180 Porto, Portugal.

E-mail: csp@imbc.up.pt plants, yeasts, nematodes, parasites, fungi, and viruses (for a review, see Simões and Faro 2004). Plant APs from seeds, leaves, and flowers of several species of gymnosperms, dicotyledons, and monocotyledons have been detected, extracted, and characterised (Simões and Faro 2004). The majority of the APs that have been studied are synthesised as proenzymes and subsequently converted to single- or double-chained mature enzymes. The precursors are characterised by a signal sequence for translocation into the endoplasmic reticulum (ER), followed by a prosegment of about 40 amino acids and two domains $(\mathrm{N}$ terminal and C-terminal domains) separated by an insertion of about 100 amino acids, named the plant-specific insert (PSI). Processing of plant APs starts with the removal of the signal sequence upon translocation to the ER, followed by cleavage of the prosegment and total or partial removal of the internal PSI, although the order of events is variable in different APs. The PSI is present only in plant APs and shows no similarities with any segment of the animal counterparts, but has a significant homology with saposins, animal sphingolipid activator proteins (Simões and Faro 2004). On the basis of studies of the crystal structures of phytepsin (Kervinen et al. 1999) and cardosin A (Frazão et al. 1999), it has been proposed that the PSI is located at the surface of the molecule, as each of these proAPs binds to the plasma membrane, at the PSI region, prior to transport into the vacuole, where the PSI could be removed (Kervinen et al. 1999). The functions of the PSI remain elusive, but a role in vacuolar targeting of plant AP precursors has been proposed. Deletion of the 
PSI from phytepsin resulted in its redirection to the apoplast (Törmäkangas et al. 2001), but in a study of PSI deletion mutants of two vacuolar soybean APs, one mutant remained targeted to the vacuole, while the other did not (Terauchi et al. 2006). Egas et al. (2000) have demonstrated that the cardosin A PSI is a potent inducer of vesicle leakage and proposed the idea that AP precursors are bifunctional molecules, containing a membrane-destabilising domain in addition to the protease domain. The authors also suggested that the PSI may be involved in defence mechanisms and/or act as an effector of cell death (Egas et al. 2000, Simões and Faro 2004).

In the majority of plants, APs are located in seeds, whether quiescent or germinating, where they are believed to participate in storage protein cleavage and/or maturation (Mutlu and Gal 1999, Simões and Faro 2004). They have also been found in leaves, and in species of the genus Cynara, they are abundantly present in flowers (Ramalho-Santos et al. 1997). Cardosins are plant APs originally isolated from the flowers of Cynara cardunculus L. (cardoon) and are responsible for the milk-clotting activity made use of in the cheese-making industry. Two APs from cardoon, cardosin A and cardosin B, have been isolated and extensively characterised (Ramalho-Santos et al. 1996, 1997, 1998a, b; Veríssimo et al. 1996; Faro et al. 1998; Vieira et al. 2001). More recently, two additional cardosins have been isolated, namely, cardosin $\mathrm{C}$ and cardosin D, which share high sequence similarity with cardosin A (Pimentel et al. 2007). Cardosin A is the more abundant and is mainly accumulated in protein storage vacuoles of the stigmatic papillae and vacuoles of the epidermic cells of the style, suggesting a possible role in the pollen-pistil interaction (Ramalho-Santos et al. 1997, Duarte et al. 2006). Procardosin A, the precursor of cardosin A, undergoes proteolytic processing as the flower matures, and during this process, the PSI is completely removed prior to the prosegment. Its conversion into the mature form is likely to occur inside the vacuoles (RamalhoSantos et al. 1998b, Simões and Faro 2004). Cardosin B has been shown to be localised in the extracellular matrix of the stylar transmitting tissue (Vieira et al. 2001, Duarte et al. 2006) and a role in the remodelling or degradation of the pistil extracellular matrix during pollen tube growth has been suggested. In fully mature embryo sacs, cardosin B localisation is closely correlated with events of programmed cell death in the nucellus of $C$. cardunculus, suggesting involvement in ovule and embryo sac development (Figueiredo et al. 2006). It is also present along the pollen tube pathway leading to the synergids and the egg cell. The presence of cardosin B in these specific regions may be associated with a role in softening and loosening of the cell wall, presumably facilitating pollen tube progression and/or the passage of nutritive substances through this region, nourishing the embryo sac (Figueiredo et al. 2006). Given the localisation of these two cardosins in cardoon flowers, it is possible that both may perform important roles during plant sexual reproduction. Together, cardosin A and B constitute an excellent model to study the secretory pathway and vacuolar sorting signals in plants. These APs, while sharing a high degree of homology, namely, in the saposin-like PSI sequence, show distinct subcellular localisations: cardosin A being targeted to the vacuole and cardosin B being secreted.

A systematic study of the spatial and temporal pattern of cardosin A and B expression and its developmental regulation is being undertaken with the aim of gaining insights into the biological roles of these proteinases (RamalhoSantos et al. 1997, Vieira et al. 2001, Duarte 2005, Duarte et al. 2006, Figueiredo et al. 2006). Here, we determined cardosin A and B expression patterns in postembryonic germinating seeds. Both cardosins were detected in germinating seeds, but cardosin A appeared to be synthesised de novo in a developmentally regulated manner, with its precursor form predominating in the first steps of seed development. This is an unexpected pattern that poses new questions relating to a possible physiological role of this PSI-containing form of cardosin A. Also, cardosin A colocalises with the PSI in intracellular protein bodies in the embryo and also appears to be localised extracellularly.

\section{Material and methods}

\section{Plant material}

Cardoon (Cynara cardunculus L.) seeds were collected from plants grown in the field, in the central region of Portugal (Ansião, Leiria), and were stored at room temperature prior to analysis. Seeds were stratified for $48 \mathrm{~h}$ at $4{ }^{\circ} \mathrm{C}$ prior to surface sterilisation with $70 \%(\mathrm{v} / \mathrm{v})$ ethanol and $20 \%(\mathrm{v} / \mathrm{v}) \mathrm{NaOCl}_{4}$. After $16 \mathrm{~h}$ of hydration, seeds were placed in petri dishes on top of a wet filter paper layer at $20^{\circ} \mathrm{C}$ at a photoperiod of $16 \mathrm{~h}$ light and $8 \mathrm{~h}$ dark for 15 days. Samples were taken at different time points, divided into seed coat with attached endosperm and the embryo, and frozen in liquid nitrogen. The sampling was made taking into account not only the time of imbibition but also the morphologic aspect of the seedling, in order to achieve a trial as homogeneous as possible.

\section{Total RNA extraction and RT-PCR}

Seed fractions were ground to powder in liquid nitrogen and total RNA extraction was performed using the Invisorb Spin Plant RNA Mini Kit (Invitek, Berlin, Federal Republic of Germany), according to the supplied protocol. RT-PCR analysis was carried out in order to detect cardosin-related transcripts using Ready-to-go RT-PCR beads (Amersham, Freiburg, Federal Republic of Germany). Poly (dT), supplied with the kit, was used as first strand primer. The specific primers used for cardosin A were the following: forward, 5' - CTC GGC CTT TCA CTT 
CAA ACG - 3'; reverse, 5' - CGG GTT GTA TCT TAG ATC GG - 3'; generating a final PCR product of $417 \mathrm{bp}$. Those used for cardosin B were the following: forward, $5^{\prime}$ - GAT CTC GGC TGG GAA AGC G $3^{\prime}$; reverse, 5' - ATA CCA TTG CAG TCT ACT ATC G - 3'; generating a final PCR product of $686 \mathrm{bp}$. One microgram of total RNA from each sample was used in the reaction and reverse transcribed $\left(42{ }^{\circ} \mathrm{C}, 30 \mathrm{~min}\right)$ into single-stranded cDNA. The template was denatured at $95^{\circ} \mathrm{C}$ for 5 min, and subsequent PCR amplification involved 35 cycles of denaturation $\left(94^{\circ} \mathrm{C}, 30 \mathrm{~s}\right)$, annealing $\left(54^{\circ} \mathrm{C}, 20 \mathrm{~s}\right.$ for cardosin $\mathrm{A}$ and $62^{\circ} \mathrm{C}$, $20 \mathrm{~s}$ for cardosin $\mathrm{B})$, and elongation $\left(72^{\circ} \mathrm{C}, 2 \mathrm{~min}\right)$, followed by a final extension step of $7 \mathrm{~min}$ at $72{ }^{\circ} \mathrm{C}$. The same RT-PCR analysis was employed using tubulin as a control, with specific primers designed on the basis of the high homologies found between database sequences.

\section{Protein extraction and Western blotting analysis}

Seed fractions at different stages of development were ground in liquid nitrogen in a mortar and pestle and then homogenised with $0.06 \mathrm{M}$ Tris$\mathrm{HCl}, \mathrm{pH} 6.8,1 \mathrm{mM}$ phenylmethylsulfonyl fluoride, and 2.5\% (w/v) sodium dodecyl sulfate. Extracts obtained were centrifuged at $11000 \mathbf{g}$ for $20 \mathrm{~min}$ at $6{ }^{\circ} \mathrm{C}$, and supernatants were collected and centrifuged at $11000 \mathrm{~g}$ for $15 \mathrm{~min}$ at $6^{\circ} \mathrm{C}$. Protein fractions were combined with a bromophenol-based sample buffer, after protein quantification according to the Bradford method (Bradford 1976). Samples containing about $10 \mu \mathrm{g}$ of total protein were loaded onto $12.5 \%$ polyacrylamide gels for sodium dodecyl sulfate-polyacrylamide gel electrophoresis. Following electrophoretic separation, proteins were blotted onto a nitrocellulose membrane with a Tris-glycine-methanol buffer. For immunodetection, the membranes were incubated in blocking solution $(5 \%[\mathrm{w} / \mathrm{v}]$ skim milk and $1 \%[\mathrm{w} / \mathrm{v}]$ bovine serum albumin in Tris-buffered saline [TBS], containing $0.6 \%[\mathrm{v} / \mathrm{v}]$ Tween 20 ) for $1 \mathrm{~h}$ at room temperature and then incubated overnight with a 1:750 dilution of the primary antibody in blocking solution at $4{ }^{\circ} \mathrm{C}$. The membranes were washed three times in TBS containing $0.1 \%(\mathrm{v} / \mathrm{v})$ Tween 20 and incubated with a $1: 1000$ dilution of anti-rabbit immunoglobulin $\mathrm{G}(\mathrm{IgG})$ conjugated to alkaline phosphatase for $30 \mathrm{~min}$ at room temperature. The membranes were washed and detection was performed using nitro-blue tetrazolium chloride-5bromo-4-chloro-3-indolyl phosphate, a chromogenic substrate for alkaline phosphatase. The primary antibodies used had been raised against specific small peptides: SSKCINSK in the heavy chain of cardosin A and CVIHPRYDSGD in the heavy chain of cardosin B.

\section{Seed fixation and embedding}

Seeds were fixed for $2 \mathrm{~h}$ at room temperature in $1.25 \%(\mathrm{w} / \mathrm{v}) \mathrm{Na}-$ piperazine-N,N'-bis(2-ethanesulfonic acid) (Na-PIPES) buffer, $\mathrm{pH} 7.2$ containing $4 \%(\mathrm{v} / \mathrm{v})$ paraformaldehyde, $0.5 \%(\mathrm{v} / \mathrm{v})$ glutaraldehyde, $2 \%$ $(\mathrm{w} / \mathrm{v})$ sucrose, $0.05 \%(\mathrm{w} / \mathrm{v})$ calcium chloride, and $0.025 \%(\mathrm{v} / \mathrm{v})$ Tween 20. Pieces were washed in $2.5 \%$ (w/v) Na-PIPES buffer, $\mathrm{pH} 7.2$, and dehydrated in a graded ethanol series, running from 25 to $100 \%$ (v/v) at $10 \mathrm{~min}$ intervals. After dehydration, the pieces were incubated in a graded series of London Resin White resin (medium grade, catalysed) and ethanol $(1: 3,1: 2,1: 1,2: 1,3: 1,1: 0)$ at room temperature overnight. The embedded pieces were polymerised at $55^{\circ} \mathrm{C}$ in London Resin White resin using gelatine capsules.

\section{Seed morphology and protein detection assays}

For morphological studies, semithin sections $(2 \mu \mathrm{m})$ were cut with glass knives, stained with a $1: 1(\mathrm{v} / \mathrm{v})$ solution of $1 \%(\mathrm{w} / \mathrm{v})$ Azure II and $1 \%$ $(\mathrm{w} / \mathrm{v})$ methylene blue in $1 \%(\mathrm{w} / \mathrm{v})$ sodium borate, placed on glass slides and observed with a bright-field microscope.

For histochemical assays, semithin sections $(2 \mu \mathrm{m})$ were cut with glass knives, placed onto poly-L-lysine-coated glass slides and incubated at $70{ }^{\circ} \mathrm{C}$ for $15 \mathrm{~min}$. Slides were then submerged in $6 \%(\mathrm{v} / \mathrm{v})$ hydrogen per- oxide for $20 \mathrm{~min}$ and washed three times with distilled water. Sections were stained in a solution containing $1 \%(\mathrm{w} / \mathrm{v})$ bromophenol blue in $2 \%$ $(\mathrm{v} / \mathrm{v})$ acetic acid and $1 \%(\mathrm{w} / \mathrm{v})$ mercury chloride for $2 \mathrm{~h}$. Slides were then washed in $0.5 \%(\mathrm{v} / \mathrm{v})$ acetic acid for $5 \mathrm{~min}$ and in distilled water. As a negative control, seed sections were incubated in a solution containing $10 \%(\mathrm{v} / \mathrm{v})$ acetic anhydride in pyridine for 2 to $4 \mathrm{~h}$ prior to staining.

\section{Immunofluorescence and immunogold labelling}

Semithin sections $(2 \mu \mathrm{m})$ were cut with glass knives, placed on poly-Llysine-coated glass slides and used for immunofluorescence. After epitope exposition using a sodium $m$-periodate saturated solution, sections were incubated in TBS with $0.2 \%(\mathrm{v} / \mathrm{v})$ Tween 20 and $10 \%(\mathrm{v} / \mathrm{v})$ goat serum for $1 \mathrm{~h}$ at room temperature. Incubations with polyclonal antibodies against the cardosin A heavy chain (the same as used for the Western blotting assay) and the PSI region (KNNDKSSGGIHDE) were performed overnight at $4{ }^{\circ} \mathrm{C}$ in a wet chamber, and Alexa $488 \mathrm{IgG}$ (heavy plus light chains) was used as secondary antibody (1:400). Sections were washed and mounted on glass slides with the Vectashield mounting medium (Vector Laboratories, Burlingame, Calif., U.S.A.).

Sections for transmission electron microscopy were obtained with a diamond knife, and gold sections were placed in 400-mesh square nickel grids. After epitope exposition, grids were placed in drops of blocking solution (TBS with $0.2 \%[\mathrm{v} / \mathrm{v}]$ Tween $20,5 \%[\mathrm{v} / \mathrm{v}]$ goat serum, and $0.8 \%[\mathrm{w} / \mathrm{v}] \mathrm{NaCl})$ for $30 \mathrm{~min}$, and incubation with primary antibodies (referred to above) (1:200 dilution in blocking solution) was performed overnight at $4{ }^{\circ} \mathrm{C}$ in a wet chamber. After rinsing in blocking solution, grids were incubated for $90 \mathrm{~min}$ in gold-labelled goat anti-rabbit IgG (heavy and light chains) (gold, $10 \mathrm{~nm}$ in diameter) diluted 40 times. Sections were poststained in $2 \%(\mathrm{v} / \mathrm{v})$ aqueous uranyl acetate saturated solution for $7 \mathrm{~min}$ and in lead citrate for $4 \mathrm{~min}$. Ultrathin sections were examined with a Zeiss $10 \mathrm{C}$ electron microscope.

\section{Results}

\section{Morphological and histochemical characterisation of cardoon seeds}

Cardoon seeds have a thick, hard external seed coat, which is highly impermeable to water and is fused with the pericarp, the mature ovary wall, and a thin single cell-layered endosperm between the cell coat and the embryo. The endosperm is firmly attached to the seed coat, both tissues being readily detached from the embryo during manual separation. The embryo presents two well developed cotyledons and an embryo axis with a reduced hypocotyl and a radicle. The radicle is the first part of the embryo to emerge from the seed coat (Fig. 1). The seed coat has multiple cell layers and is constituted mainly of sclerenchymatous cells. Germination is epigeal; therefore, as the hypocotyl extends, it carries the cotyledons above ground. After germination, the developing seedling presents a radicle, hypocotyl, and two well developed cotyledons (Fig. 1). Histological analysis by light microscopy reveals tissue differentiation of the embryo into protoderm, procambium, and ground meristem (Fig. 2a). The seed coat tissues appear crushed and the cells are empty 


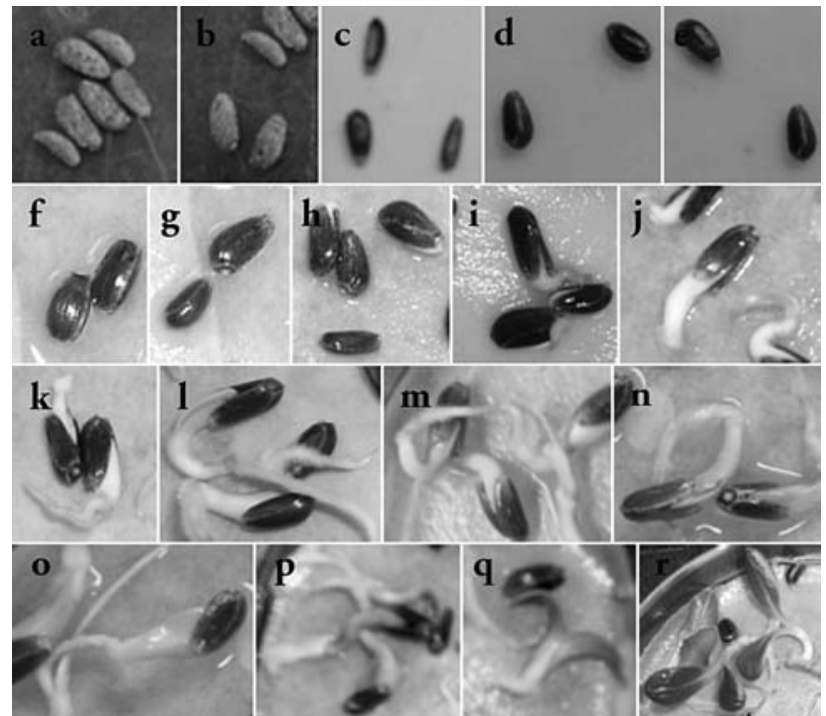

Fig. 1 a-r. Seed postembryonic development stages. Dry seed (a); sterile seed (b); seed after $16 \mathrm{~h} \mathrm{(c),} 24 \mathrm{~h} \mathrm{(d),} 36 \mathrm{~h} \mathrm{(e),} 48 \mathrm{~h}(\mathbf{f}), 60 \mathrm{~h} \mathrm{(g),} 72 \mathrm{~h}$ (h), $84 \mathrm{~h}(\mathbf{i}), 96 \mathrm{~h}(\mathbf{j}), 108 \mathrm{~h}(\mathbf{k}), 120 \mathrm{~h}(\mathbf{l}), 7$ days $(\mathbf{m}), 8$ days $(\mathbf{n}), 9$ days $(\mathbf{o})$ 10 days $(\mathbf{p}), 12$ days $(\mathbf{q}), 15$ days $(\mathbf{r})$ hydration

(Fig. 2b). The cotyledons of cardoon seeds appear to be rich in storage proteins. Parenchymatous cotyledonary cells appear to be storage parenchyma presenting an abun- dance of spherical bodies which stain positively for proteins (Fig. 2c, d). No staining for proteins was observed in either the seed coat or the endosperm (data not shown).

\section{Cardosin A mRNA detection in cardoon seeds}

Detection of cardosin A transcripts by RT-PCR revealed that these are present in dry seeds in the embryo fraction (Fig. 3a) and are then virtually undetectable until after 72-84 h (3 days) of hydration. At this point, which corresponds to radicle emergence, cardosin A mRNA is present in the embryo and remains in subsequent developmental stages until 15 days after hydration (Fig. 3a). As a RTPCR control, detection of tubulin transcript was used (Fig. 3b).

\section{Detection of cardosin A by Western blotting}

Precursor cardosin A (64 kDa) was detected in the embryo fraction and in almost every sample taken at different time points until $120 \mathrm{~h}$, the stage correspondent to the appearance of the first green cotyledonary leaves (Fig. 4). A band at about $45 \mathrm{kDa}$ was also detected at almost all
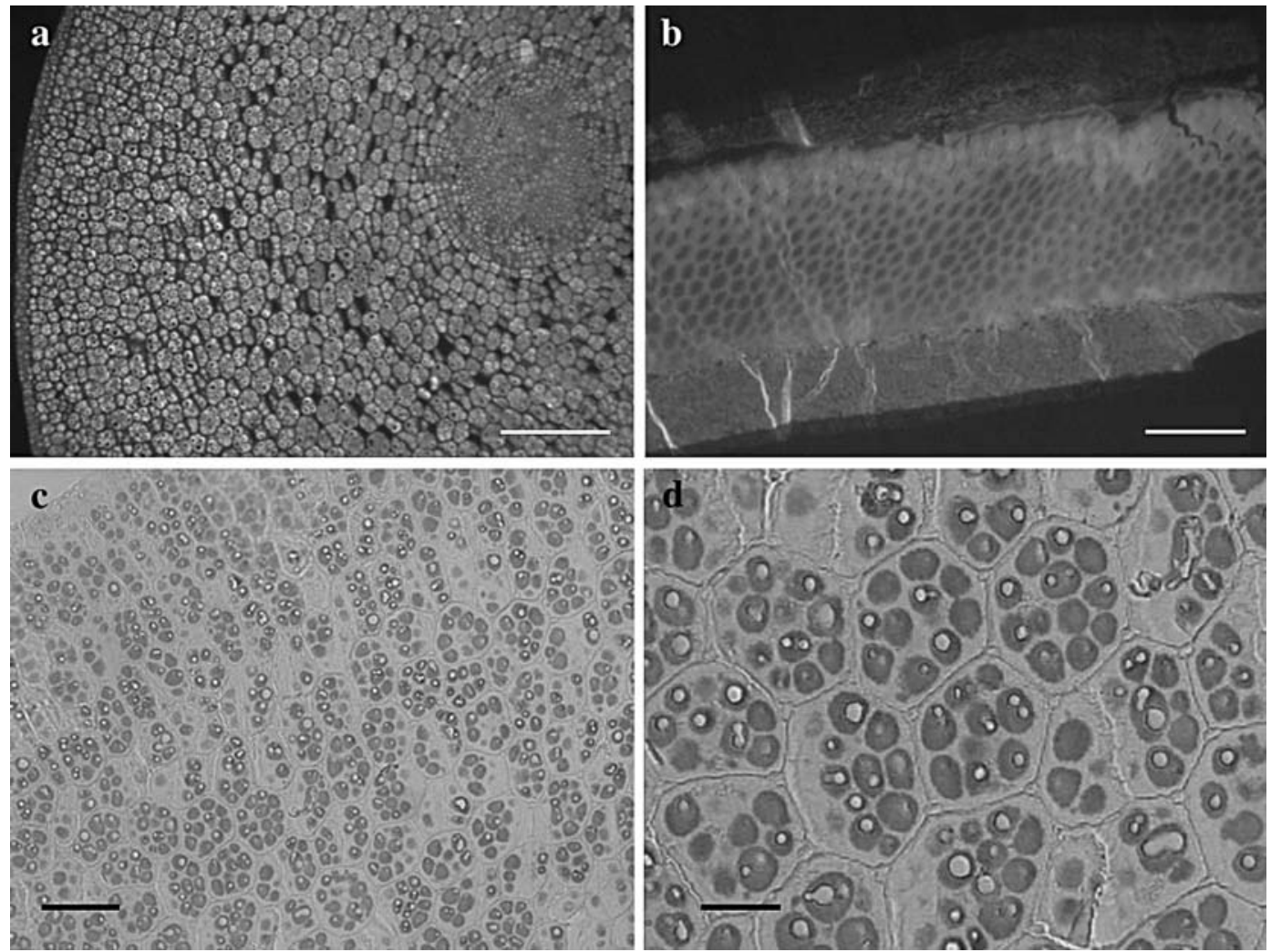

Fig. 2. Seed cross sections stained with Azure II (a and b) and for protein detection (c and d). Cotyledon (a) and seed coat and endosperm (b) sections revealing the seed morphology (c and d). Dark grey bodies correspond to protein depositions. Bars: a, $40 \mu \mathrm{m} ; \mathrm{b}$ and d, $20 \mu \mathrm{m} ; \mathrm{c}, 50 \mu \mathrm{m}$ 

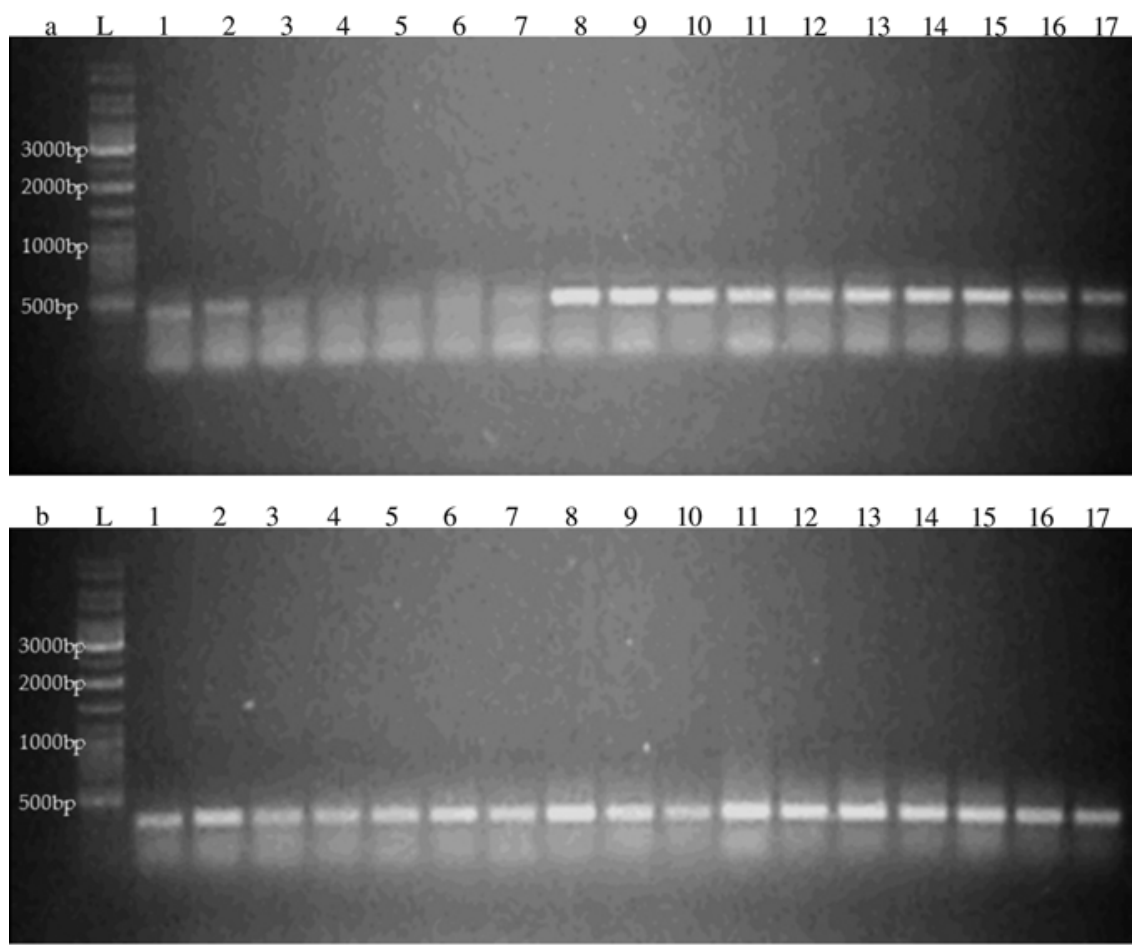

Fig. 3a, b. Cardosin A mRNA detection in the embryo during postembryonic development of cardoon seed. a A band at approximately 417 bp corresponding to cardosin A mRNA is detectable. De novo synthesis is observed from $84 \mathrm{~h}$ and remains stable. b Beta tubulin mRNA (340 bp) was used as an internal control. $L$ Ladder; 1 dry seed; and seed after $16 \mathrm{~h}(2), 24 \mathrm{~h}(3), 36 \mathrm{~h}(4), 48 \mathrm{~h}$ (5), $60 \mathrm{~h} \mathrm{(6),} 72 \mathrm{~h} \mathrm{(7),} 84 \mathrm{~h} \mathrm{(8),} 96 \mathrm{~h} \mathrm{(9),}$ $108 \mathrm{~h}(10), 120 \mathrm{~h}(11), 7$ days (12), 8 days (13), 9 days (14), 10 days (15), 12 days (16), 15 days (17) hydration

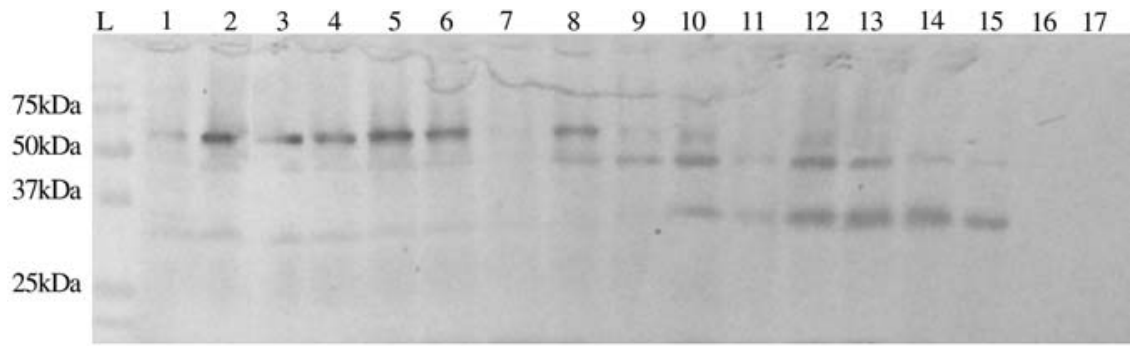

Fig. 4. Western blot of the embryo during postembryonic development labelled with antibody against cardosin A heavy chain. The precursor form $(64 \mathrm{kDa})$ is detectable in the first stages of development (until approximately $120 \mathrm{~h}$ ), while the mature form ( $31 \mathrm{kDa})$ is faintly detectable in the first

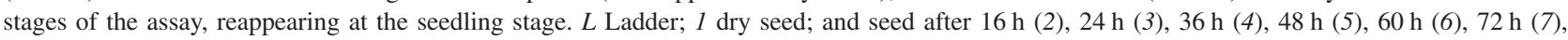
$84 \mathrm{~h}(8), 96 \mathrm{~h}$ (9), $108 \mathrm{~h}$ (10), $120 \mathrm{~h}$ (11), 7 days (12), 8 days (13), 9 days (14), 10 days (15), 12 days (16), 15 days (17) hydration

time points studied and corresponds to an intermediate form of the protein, which has already been described (Ramalho-Santos et al. 1998b). The processed mature form $(31 \mathrm{kDa})$ could be very faintly detected in the first hours after imbibition until stage $6(60 \mathrm{~h})$, reappearing before the seedling stage. The mature form was detectable up until the end of the assay (Fig. 4). The presence of the precursor cardosin $\mathrm{A}$, and not of the mature form, in the first steps of seed germination and elongation was particularly interesting. The correlation between the initial detection of cardosin A mRNA and the increase in the mature form is also noteworthy. No protein was detected in the last two stages studied, corresponding to an advanced seedling stage.

\section{Cardosin B mRNA and protein detection in cardoon seeds}

Cardosin B mRNA was virtually undetectable in seeds in all the developmental stages sampled (Fig. 5a). As a RT-PCR control, detection of tubulin transcripts was used (Fig. 5b). The intermediate protein form (37 kDa) of cardosin B was detected in the embryo during the first stages after imbibition, and then gradually decreased in intensity and was almost undetectable after 72-84 h (Fig. 6).

\section{Immunocytochemical detection of cardosins} in cardoon seed tissues

Antibodies raised against cardosin A heavy chain, cardosin A PSI, and cardosin B were used in immunofluores- 

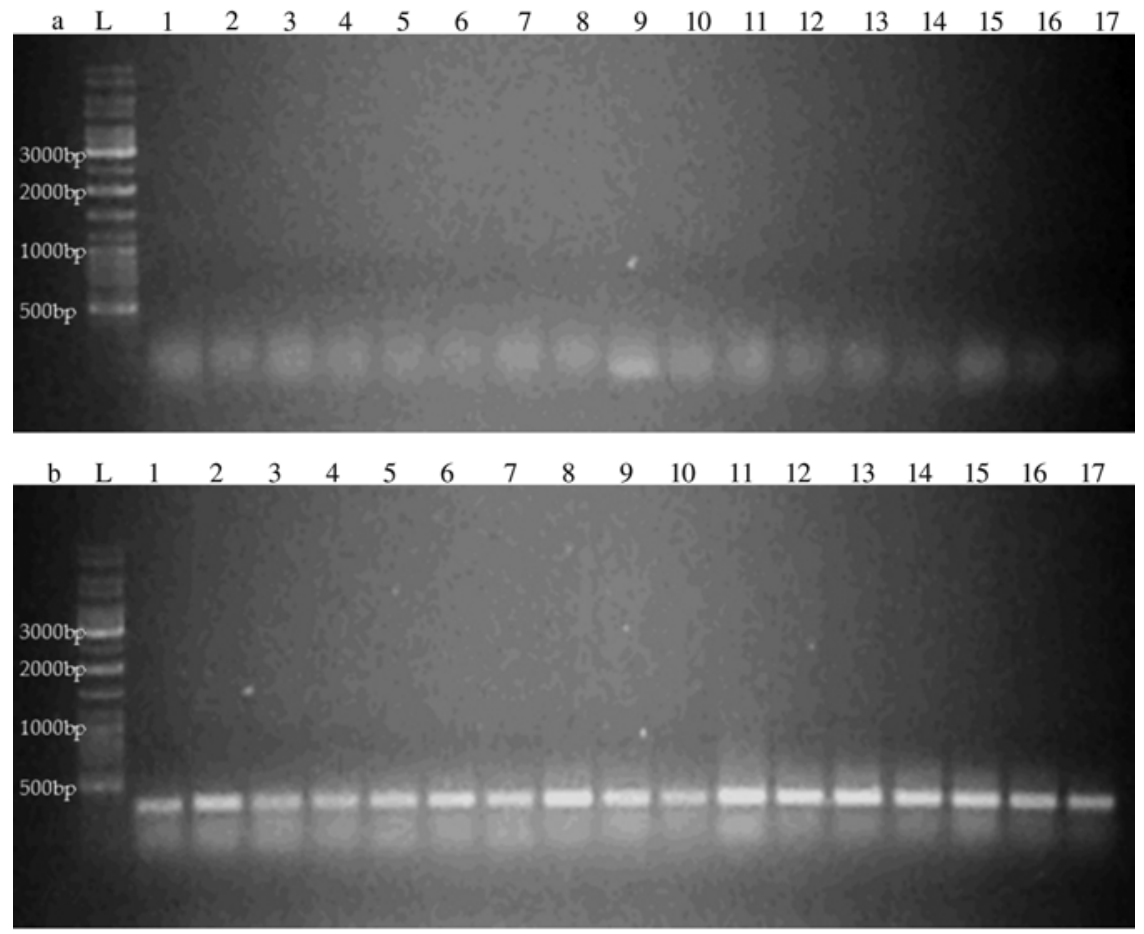

Fig. 5a, b. Cardosin B mRNA in the embryo during postembryonic development of cardoon seed. a No mRNA corresponding to cardosin B is detectable. b Beta tubulin mRNA (340 bp) was used as an internal control. $L$ Ladder; 1 dry seed; and seed after $16 \mathrm{~h}$ (2), $24 \mathrm{~h} \mathrm{(3),} 36 \mathrm{~h} \mathrm{(4),} 48 \mathrm{~h}(5), 60 \mathrm{~h}(6), 72 \mathrm{~h}$ (7), 84 h (8), 96 h (9), 108 h (10), 120 h (11), 7 days (12), 8 days (13), 9 days (14), 10 days (15), 12 days (16), 15 days (17) hydration

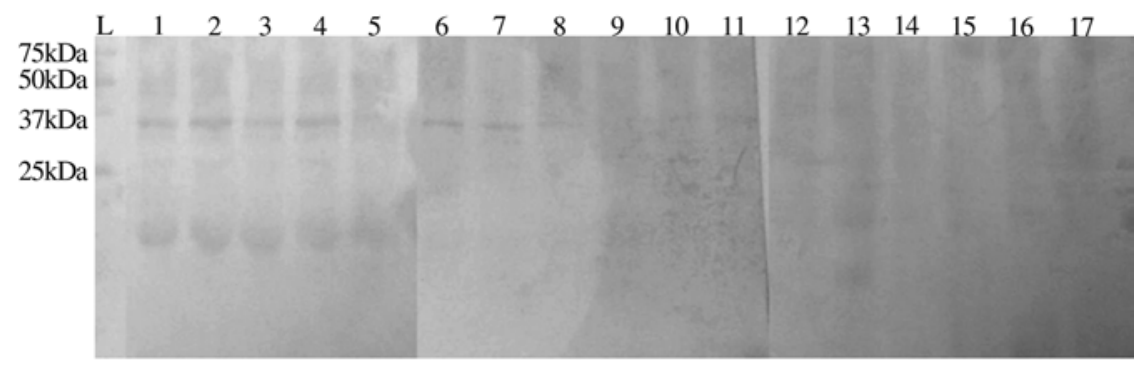

Fig. 6. Western blot of the embryo during postembryonic development labelled with antibody against cardosin B. A band at about $34 \mathrm{kDa}$, correspondent to the mature form, is detectable in the first stages, and decreases during development until the stage of radicle emergence. $L$ Ladder; 1 dry seed; and seed after 16 h (2), 24 h (3), 36 h (4), 48 h (5), 60 h (6), 72 h (7), 84 h (8), 96 h (9), 108 h (10), 120 h (11), 7 days (12), 8 days (13), 9 days (14), 10 days (15), 12 days (16), 15 days (17) hydration

cence detection of both proteins in seed tissues. Samples were taken at the time of radicle emergence. Sections incubated with anti-cardosin B primary antibody showed no labelling (data not shown). In cotyledons, labelling for cardosin A appeared in protein bodies (Fig. 7a) and was also intense in cell walls near the periphery, in the protoderm outer cell wall, and in the endosperm cell wall (Fig. 7c). Using the antibody raised against the PSI region, labelling was detected in the protein bodies, similar to the results obtained using anti-cardosin A (Fig. 7e, f). No labelling appeared in control sections where primary antibody was omitted (Fig. 7b, d), despite the high autofluorescence of these types of tissues.

\section{Localisation of cardosin A and the PSI} by immunoelectron microscopy

Cardosin A, labelled with the same antibodies described previously, was located in large protein bodies and cell walls of cotyledon cells (Fig. 8a, b). Protein bodies appeared as roughly spherical or irregular in outline. It is clear that antibodies raised against the PSI labelled exactly the same structures, i.e., protein masses and cell walls (Fig. 8c, d). Some gold granules were observed inside the vacuoles around the protein bodies (Fig. 8c, d), but in view of the labelling specificity we do not consider this significant. 

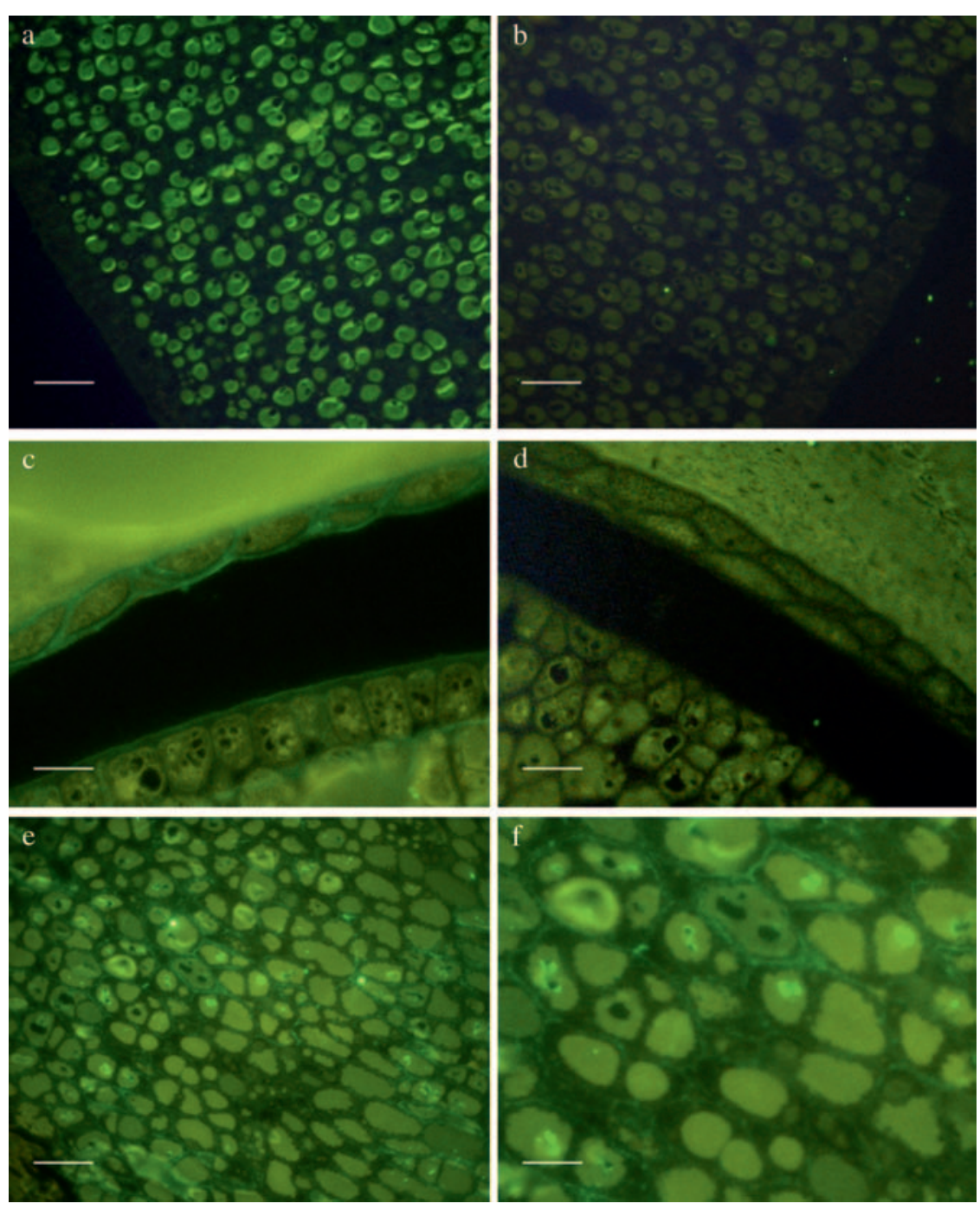

Fig. 7 a-f. Cotyledon and seed coat immunofluorescence sections at radicle emergence. An antibody against cardosin A heavy chain (a and $\mathbf{c}$ ) and another against the PSI region (e and $\mathbf{f}$ ) were used. a and $\mathbf{c}$ Fluorescent labelling can be observed in the protein bodies (a), while in the seed coat and endosperm section (c), fluorescence appears in the cell wall. e and f Labelling in the cotyledon section is evident in the cell walls. $\mathbf{b}$ and $\mathbf{d}$ In control sections, only secondary antibody was employed. Bars: a and b, $40 \mu \mathrm{m}$; $\mathrm{c}$ and $\mathrm{d}$, $20 \mu \mathrm{m}$; e, $30 \mu \mathrm{m}$; f, $10 \mu \mathrm{m}$

\section{Discussion}

A systematic study of cardosin A and B expression in various developmental stages and organs has been undertaken, particularly in reproductive structures (Ramalho-Santos et al. 1996, 1997, 1998b; Verissimo et al. 1996; Faro et al. 1998; Vieira et al. 2001; Duarte 2005; Figueiredo et al. 2006). In the course of these studies, the temporal and spatial accumulation patterns in cardoon postembryonic seed development were determined. The data obtained in this study suggests APs may be involved in the membrane reorganisation and lipid transformation necessary for water uptake, tissue reorganisation, radicle and cotyledon growth, and senescence during seed germination, in addition to their proteolytic activities and/or processing of seed protein reserves.

\section{Cardosin A de novo synthesised from the time of radicle} emergence

Combining the RT-PCR and Western blot results for cardosin A, it is possible to highlight an important time point in cardosin A expression - radicle emergence. This suggests that mRNA and precursor cardosin A accumulated during the earliest stages of seed maturation remain in the dry seed. Subsequently, de novo synthesis occurs at the time of radicle emergence, perhaps in response to a developmental signal. This data is in accordance with the general changes in mRNA and protein expression in the context of seed germination (Bewley 1997). Structures and enzymes important for resuming metabolism are present in the dry seed. Upon imbibition, enzymes already present are activated and new ones are synthesised. Pre- 


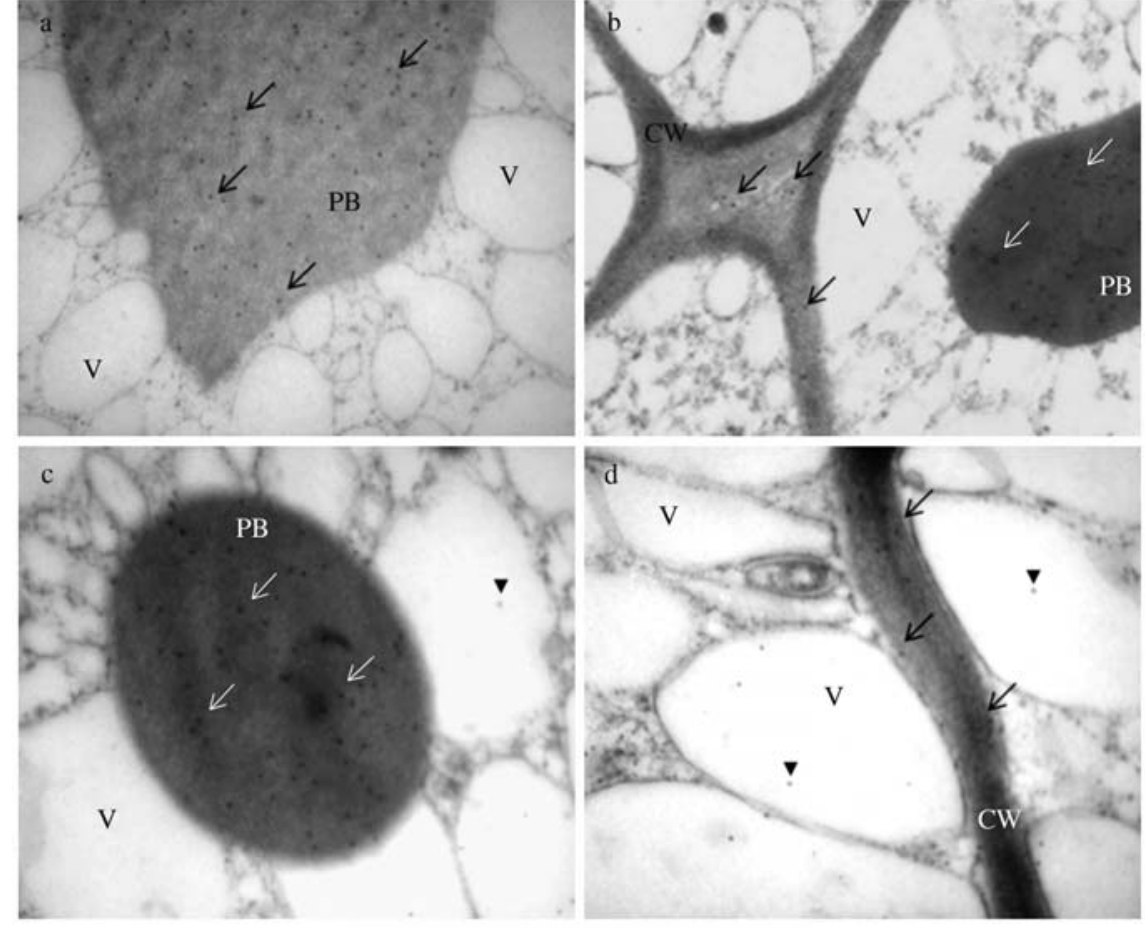

Fig. 8 a-d. Cotyledon immunogold sections, at the time of radicle emergence, using an antibody against cardosin A heavy chain (a and b) and another against the PSI region (c and d). Gold dots can be observed inside the protein bodies, in the cell wall, and in the intercellular spaces. Arrowheads indicate gold dots in vacuoles. $C W$ Cell wall; $P B$ protein body; $V$ vacuole. Bars: a, $0.4 \mu \mathrm{m}$; b, $0.2 \mu \mathrm{m} ; \mathrm{c}$ and $\mathrm{d}, 0.15 \mu \mathrm{m}$ formed mRNAs (long-lived mRNAs) have also been found to be present in the dry embryo and those encoding proteins required for early germination may be used transiently, being replaced by new transcripts at later stages (Bewley 1997). Barley AP-encoding mRNAs have been detected in dry, metabolically inactive embryos and seed aleurone cells; thus, they belong to a class of stored transcripts present in mature seeds. Stored mRNAs are available for translation immediately upon hydration, before the embryo mRNA synthesis begins (Törmäkangas et al. 1994). The described pattern of cardosin A expression suggests a finely tuned developmental regulation and prompts an analysis of its possible role in the physiology of seed germination and postgermination.

\section{Procardosin A in protein bodies: a possible tissue-dependent pattern of accumulation}

In immunolocalisation studies, cardosin A was detected in embryo cells at the time of radicle emergence, inside protein bodies, and also, which has never been described before, in cell walls, particularly in cotyledonary and endosperm cells. Interestingly, the labelling for cardosin A in these structures colocalised with that for the PSI, suggesting that the procardosin $\mathrm{A}$ is the form present in these structures. This is a new observation, to our knowledge, as it has been assumed that the PSI is degraded after removal from the proenzyme (Ramalho-Santos et al. 1998b) and, therefore, its function is achieved while integrated in the precursor form. This observation correlates with the fact that the precursor is the form almost exclusively detected in the seed in Western blots, before and even after radicle emergence. Further studies of the functional relevance of these findings are needed in combination with detailed analysis of the intracellular trafficking and processing of cardosin A in seeds, which is apparently different from that described for other organs. So far, immunocytochemistry assays have revealed that this AP accumulates in the protein storage vacuoles of the epidermal papillae, and that the last processing event, giving rise to the mature form of cardosin A, occurs in this subcellular compartment. Labelling for cardosin A has also been observed at the surface of the stigmatic papillae, suggesting the secretion of a portion of the AP synthesised in these cells (Ramalho-Santos et al. 1997, Duarte 2005). In embryo tissues, cardosin A was located in protein bodies, probably ER-derived, and could be detected immediately after imbibition. The mechanism of protein retention in protein bodies and its functional significance have yet to be determined. A model for ER protein retention has been proposed by Vitale and Ceriotti (2004), in which specific domains of the proteins may interact directly with the lipids of the ER membrane. The demonstrated ability of the PSI to interact with membranes (Egas et al. 2000) could justify the presence of the car- 
dosin A precursor form, and not its mature form, in protein bodies. Different localisations for an AP in different organs in vivo have not been previously described, which makes this report the first to do so. Related results were described by Drakakaki et al. (2006), who demonstrated that a recombinant protein was efficiently secreted from leaf cells, while it was retained in ER-derived prolamin bodies and protein storage vacuoles within endosperm cells. These data suggest that the intracellular deposition and modification of proteins can be tissue-dependent. Our results suggest that this differential accumulation pattern may be inherent of storage tissues. In cardoon pistils, the cardosin A mature form is mainly detected in the vacuoles, and in seeds, it is the precursor form that accumulates in ER-derived protein bodies. This fact strongly suggests a tissuedependent intracellular localisation for cardosin A.

\section{Physiological roles for cardosin A other than proteolysis}

Plant APs have been proposed to be involved in storageprotein processing during seed development and in protein degradation during seed germination (for a review, see Mutlu and Gal 1999, Runeberg-Roos et al. 1994, Hiraiwa et al. 1997, Mutlu et al. 1998, Chen et al. 2002). The presence of procardosin A in the protein bodies of cotyledonary cells raises the question of its functional significance. Unlike other zymogens, procardosins are active and may therefore have a role in proteolysis (Simões and Faro 2004). The presence of the precursor form in protein bodies could reflect a possible role in the catabolism and processing of seed reserves, or this could be an intermediate accumulation point from where the protein could be secreted to the outer cell wall, or follow the presumed pathway via the Golgi to the vacuole, where it would be converted to the mature form. An AP, but not the PSI, was found in protein bodies of Arabidopsis thaliana, colocalising with seed storage protein (Mutlu et al. 1999). However, an AP from barley grains (Sarkkinen et al. 1992) was unable to degrade seed globulins, suggesting that it may not be involved in the hydrolysis of storage proteins. Moreover, Martilla et al. (1995) detected a twofold increase in the unhydrolysed form of barley AP throughout germination. Since the barley APs appeared in all living tissues, this suggested that, rather than mobilising storage proteins, they could play a role in basic metabolism in seeds, namely, regulatory functions, resembling the lysosomal enzyme cathepsin D. The fact that the mature processed form appears after approximately $108 \mathrm{~h}$ implies that both forms of cardosin A, precursor and mature, may have different physiological roles in germinating seeds. This hypothesis is supported by their differential localisation: the mature form is localised in the vacuoles (not shown) and the precursor within the protein bodies.

\section{Role of procardosin A in membrane rearrangement during (post-)germination}

Germination begins with the uptake of water by the dry seed, i.e., imbibition, and cell enlargement and division are initiated in the embryo. The influx of water results in perturbation of membranes, leading to immediate and rapid leakage of solutes and low-molecular-weight metabolites. Rapid changes in physiology and structural organisation occur, involving alterations of membrane structure and function (Bewley 1997). On the basis of the work of Egas et al. (2000), Simões and Faro (2004) have proposed that AP precursors are bifunctional molecules containing a membrane-destabilising domain in addition to their protease domain. Egas et al. (2000) demonstrated that recombinant PSI is able to interact with phospholipid vesicles and to induce leakage of their contents, in a $\mathrm{pH}$ - and lipiddependent manner. They observed the same activity profile for procardosin A, concluding that the PSI of plant APs mediates the interaction of their precursors with phospholipid membranes and induces membrane permeabilisation. Thus, an important role could be assigned for the procardosin A PSI in the structural changes of membranes observed during the processes of seed germination and seedling growth and during water uptake and solute leakage. Frazão et al. (1999) have also proposed a mechanism by which cardosin A could reach the cell surface of the style to interact with a putative pollen receptor. Those authors suggested that cardosin A could be transported in association with the membrane, via the PSI domain of the precursor. In another approach, Brodelius et al. (2005), using antibodies against the PSI from cyprosin, located the PSI in protective tissues, proposing a role in the biogenesis of membranes in tissues with high growth rates, where a high turnover of lipids is expected. The presence of cardosin A in the cell walls could be explained by a possible involvement of PSI in membrane lipid conversion during the processes of water uptake and solute leakage and in actively growing tissues. This would also explain the persistence of cardosin A (procardosin A) in growing seedlings.

\section{Cardosin B may be involved in structural alterations} in the cell walls and tissues undergoing cell death

Radicle protrusion through the structures surrounding the embryo is the event that terminates germination and marks 
the beginning of seedling growth (Bewley 1997). The mature form of cardosin $\mathrm{B}(34 \mathrm{kDa})$ was detected from the first stages after imbibition until radicle emergence, even though no mRNA was detected, suggesting that it originated from ovary tissues. This observation suggests that this enzyme is resistant to proteolysis throughout seed maturation and desiccation and resumes its activity upon hydration. A possible role in extracellular loosening and remodelling has already been proposed (Vieira et al. 2001, Figueiredo et al. 2006). The data presented in this report supports the hypothesis that cardosin B is already present in developing seeds and, after rehydration, is activated and acts by loosening the constraining structures before the emergence of the radicle. A reduction in the resistance of the enclosing (surrounding) structures is necessary for germination to be completed (Bewley 1997). It is unlikely that the activity of this protein involves its PSI, since PSI removal is an extremely rapid event for cardosin B (our unpubl. data).

\section{More than one cardosin A involved?}

Recently Pimentel et al. (2007) revealed the existence of two new cardosins, $\mathrm{C}$ and $\mathrm{D}$, that are very similar to cardosin A (cardosin A-like). It is, therefore, not possible to distinguish them by Western blotting techniques. In the same report, the accumulation of each cardosin A-like mRNA was detected and only cardosin A mRNA was present in seeds. This indicates that the cardosin A transcripts detected in the present report probably correspond to cardosin A mRNA molecules only. However, although RTPCR products were sequenced (data not shown), the high level of similarity among cardosin $\mathrm{A}$ and the cardosin A-like proteins meant that it was not possible to prove that we detected cardosin $\mathrm{A}$ and not $\mathrm{C}$ or D.

\section{Conclusion}

APs may have other functions in seeds besides those traditionally assigned, and the PSI could have a preponderant role in this matter. The results presented here provide further insights into the functional roles of cardosins A and $\mathrm{B}$ and targeting pathways and support the proposed theory of cardosin A being a bifunctional enzyme. Procardosin A may also have a role in germination and postgermination developmental events in cardoon seeds, in addition to the possible involvement in storage protein conversion and/or degradation. The presented results suggest a possible involvement in lipid membrane destabilisation during water and solute exchanges and in actively growing structures. The observed accumulation of procardosin A in protein bodies and cell walls in seeds is different from the previously described distribution of cardosin $\mathrm{A}$ in cardoon flowers, suggesting that the mechanisms for protein assembly and transport through the endomembrane system may be tissue-dependent. Since cardosin B, an extracellular protein, was only detectable in the first stages, it could have a role in loosening the constraining structures in the first hours after seed imbibition. Together, these results contribute to the systematic ongoing study of the spatial and temporal expression of cardosins in cardoon, with the aim of unravelling their biological significance throughout plant development.

\section{Acknowledgments}

These work was supported by funding from the FCT (Fundação para a Ciência e Tecnologia, Portugal) within the project POCTI/39765/BME/ 2001. We thank Rui Fernandes for all the support and suggestions for the microscopy experiments, particularly electron microscopy image acquisition. C. S. Pereira, D. Soares da Costa, and S. Pereira contributed equally to this work.

\section{References}

Bewley JD (1997) Seed germination and dormancy. Plant Cell 9: 1055-1066

Bradford M (1976) A rapid and sensitive method for the quantitation of microgram quantities of protein utilizing the principle of protein-dye binding. Anal Biochem 72: 248-254

Brodelius M, Hiraiwa M, Marttila S, Karadaghi SA, Picaud S, Brodelius PE (2005) Immunolocalization of the saposin-like insert of plant aspartic proteinases exhibiting saposin $\mathrm{C}$ activity. Expression in young flower tissues and in barley seeds. Physiol Plant 125: 405-418

Chen X, Pfeil JE, Gal S (2002) The three typical aspartic proteinase genes of Arabidopsis thaliana are differentially expressed. Eur J Biochem 269: 4675-4684

Drakakaki G, Marcel S, Arcalis E, Altmann F, Gonzalez-Melendi P, Fischer R, Christou P, Stoger E (2006) The intracellular fate of a recombinant protein is tissue dependent. Plant Physiol 141: 578-586

Duarte P (2005) Biogenesis of cardosin A: expression and biosynthetic pathways. PhD thesis, Faculty of Sciences, University of Porto, Porto, Portugal

Duarte P, Figueiredo R, Pereira S, Pissarra J (2006) Structural characterization of the stigma-style complex of Cynara cardunculus (Asteraceae) and immunolocalization of cardosins A and B during floral development. Can J Bot 84: 737-749

Egas C, Lavoura N, Resende R, Brito RM, Pires E, de Lima MC, Faro C (2000) The saposin-like domain of the plant aspartic proteinase precursor is a potent inducer of vesicle leakage. J Biol Chem 275: 38190-38196

Faro C, Ramalho-Santos M, Veríssimo P, Pissarra J, Frazão C, Costa J, Lin X, Tang J, Pires E (1998) Structural and functional aspects of cardosins. Adv Exp Med Biol 436: 423-433

Figueiredo R, Duarte P, Pereira S, Pissarra J (2006) The embryo sac of Cynara cardunculus - ultrastructure of the development and localisation of the aspartic proteinase cardosin B. Sex Plant Reprod 19: 93-101 Frazão C, Bento I, Costa J, Soares C, Veríssimo P, Faro C, Pires E, Cooper J, Carrondo M (1999) Crystal structure of cardosin A, a glyco- 
sylated and Arg-Gly-Asp-containing aspartic proteinase from the flowers of Cynara cardunculus L. J Biol Chem 274: 27694-27701

Hiraiwa N, Kondo M, Nishimura M, Hara-Nishimura I (1997) An aspartic endopeptidase is involved in the breakdown of propeptides of storage proteins in protein-storage vacuoles of plants. Eur J Biochem 246: 133-141

Kervinen J, Tobin GJ, Costa J, Waugh DS, Wlodawer A, Zdanov A (1999) Crystal structure of plant aspartic proteinase prophytepsin: inactivation and vacuolar targeting. EMBO J 18: 3947-3955

Martilla S, Jones BL, Mikkonen A (1995) Differential localization of two acid proteinases in germinating barley (Hordeum vulgare) seed. Physiol Plant 93: 317-327

Mutlu A, Gal S (1999) Plant aspartic proteinases: enzymes on the way to a function. Physiol Plant 105: 569-576

Mutlu A, Pfeil JE, Gal S (1998) A probarley lectin processing enzyme purified from Arabidopsis thaliana seeds. Phytochemistry 47: 1453-1459

Mutlu A, Reddy XCSM, Gal S (1999) The aspartic proteinase is expressed in Arabidopsis thaliana seeds and localized in the protein bodies. Seed Sci Res 9: 75-84

Pimentel C, Van Der Straeten D, Pires E, Faro C, Rodrigues-Pousada C (2007) Characterization and expression analysis of the aspartic protease gene family of Cynara cardunculus L. FEBS J 274: 2523-2539

Ramalho-Santos M, Veríssimo P, Faro C, Pires E (1996) Action on bovine $\alpha_{\mathrm{s} 1}$-casein of cardosins $\mathrm{A}$ and $\mathrm{B}$, aspartic proteinases from the flowers of the cardoon Cynara cardunculus L. Biochim Biophys Acta 1297: 83-89

Ramalho-Santos M, Pissarra J, Veríssimo P, Pereira S, Salema R, Pires E, Faro C (1997) Cardosin A, an abundant aspartic proteinase, accumulates in protein storage vacuoles in the stigmatic papillae of Cynara cardunculus L. Planta 203: 204-212

Ramalho-Santos M, Pissarra J, Pires E, Faro C (1998a) Cardosinogen A. The precursor form of the major aspartic proteinase from cardoon. Adv Exp Med Biol 436: 253-258
Ramalho-Santos M, Veríssimo P, Cortes L, Samyn B, Van Beeumen J, Pires E (1998b) Identification and proteolytic processing of procardosin A. Eur J Biochem 255: 133-138

Runeberg-Roos P, Kervinen J, Kovaleva V, Raikel NV, Gal S (1994) The aspartic proteinase of barley is a vacuolar enzyme that processes probarley lectin in vitro. Plant Physiol 105: 321-329

Sarkkinen P, Kalkkinen N, Tilgmann C, Siuro J, Kervinen J, Mikola L (1992) Aspartic proteinase from barley grains is related to mammalian lysosomal cathepsin D. Planta 186: 317-323

Simões I, Faro C (2004) Structure and function of plant aspartic proteinases. Eur J Biochem 271: 2067-2075

Terauchi K, Asakura T, Ueda H, Tamura T, Tamura K, Matsumoto I, Misaka T, Hara-Nishimura I, Abe K (2006) Plant-specific insertions in the soybean aspartic proteinases, soyAP1 and soyAP2, perform different functions of vacuolar targeting. J Plant Physiol 163: 856-862

Törmäkangas K, Kervinen J, Ostman A, Teeri T (1994) Tissue-specific localization of aspartic proteinases in developing and germinating barley grains. Planta 195: 116-125

Törmäkangas K, Hadlington JL, Pimpl P, Hillmer S, Brandizzi F, Teeri TH, Denecke J (2001) A vacuolar sorting domain may also influence the way in which proteins leave the endoplasmic reticulum. Plant Cell 13: 2021-2032

Veríssimo P, Faro C, Moir A, Lin Y, Tang J, Pires E (1996) Purification, characterization and partial amino acid sequencing of two new aspartic proteinases from fresh flowers of Cynara cardunculus L. Eur J Biochem 235: 762-768

Vieira M, Pissarra J, Veríssimo P, Castanheira P, Costa Y, Pires E, Faro C (2001) Molecular cloning and characterisation of cDNA encoding cardosin B, an aspartic proteinase accumulating extracellularly in the transmitting tissue of C. cardunculus L. Plant Mol Biol 45: 529-539

Vitale A, Ceriotti A (2004) Protein quality control mechanisms and protein storage in the endoplasmic reticulum. A conflict of interests? Plant Physiol 136: 3420-3426 